\title{
News Coverage on the Kaaliyaattam and the Necessity of FolkloreJournalism
}

\author{
Deepesh. V. K. \\ Research Scholar, School of Folklore Studies, University of Calicut, \\ Malappuram, Kerala, India - 673635
}

\begin{abstract}
Kollam Sri. Pishaarikavu is a Saakteya Kavu (the kavu where the goddess personifying the creative power of the universe is worshipped) situated in the Quilandy Taluk of the calicut district in kerala. The festival of this temple (Kavu) is known as Kaaliyattam. On analyzing the media reports of this festival, it can be deduced that these do not represent the regional culture of the region. The practice of the media in interpreting folklore according to their tastes and interests has been widely criticized. On analyzing the media representation of the Kaaliyattam festival, it will be evident that the approach of the media towards folklore should undergo a seminal change. The age demands of us an attitude to convey culture on the basis of the traditional cultural psyche of the folk. The idea of folklore originates on the basis of such concept. This paper puts forwarded the necessity of formulating a new branch in journalism, viz., Folklore Journalism, by analysis the media reports of the Kaaliyattam festival and the lacunae in them.
\end{abstract}

Key words: Kaaliyattam, Festival, Folklore, Folklore Journalism

\section{Introduction}

The mass media has expanded considerably so as to encompass the entire aspects of public life as subject of news. The revolution in the field of information technology has brought positive and negative effects for the society. In such a situation, the manner and the attitude of the media in handling the traditional areas, facts, ideas etc. becomes the subject matter of live discussion. The media reverberates with the conflicts generated as a result of the attitude of the folk society on their tradition as opposed to the view points of the media towards it. Such a problem is not prevalent in other fronts as a result of the specialization now brought about in the field of journalism. Out of existing fifty and odd branches, journalistic branch competent to handle the folk tradition has not been hitherto evolved. Presently News about folklore is generated on the basis of one or more concepts of art, music, entertainment or devotion. But folklore while having the shades of the above peculiarities is also a reflection and conceptualization of the folk life. Folklore is communicated within the folk where it is generated and remain active. Mass media tries to prevent to the public the folklore existing within its particular folk situation. The doubt whether the politics and the aims of such a reporting will be beneficial to the folklore originated with the active involvement of the folk society and fostered by the successive generations. This paper attempts at exposing and discussing the method of reporting by the media especially the news media of the folklore which is considered by the folk as conceptual presentation with a view to remind the necessity of promulgating a journalistic attitude beneficial to the folk. The folklore genre of 'Utsavam, has been selected as a case example for the purpose. The aim of this paper is to justify the introduction of the new branch in journalism, by name folklore journalism, by discussing the problems generated while the utsavam 'Kaaliyattam,' in Shri Pisharikkav (In Kollam in the Calicut District of the Kerala State), which is the ritualistic elaboration of the life of the folk, has been subjected to news reporting.

For this a general purview of the news reporting of the Utsavam (festival) 'Kaaliyattam' of Kollam Pisharikkav has to be carried out. The news item in the Malayalam dailies by name Malayala Manorama ${ }^{3}$, Mathrubhumi $^{4}$, Deshabhimani ${ }^{5}$, Madhyamam ${ }^{6}$ and Janmabhumi ${ }^{7}$ are subjected to analysis for the study.

\section{News-A Purview}

The consecration and flag hoisting for the Kaaliyattam Utsavam (Festival) of Pisharikkav took place on $29^{\text {th }}$ March (Meenam - 15 of the Malayalam Era) 2013. It is believed that Bhagavathi (goddess) who set out from Quilon (Kollam in the Southern part of Kerala) towards north, reached an auspicious vicinity fit for her abode, proclaimed her presence and this place in Panthalayani also came to be known as Kollam. The Utsavam of the Bhagavathi at the 'kavu' which was instrumental in uniting the inhabitants of various places and societies from the seashore to the valleys of the mountain interspersed with various legends, myths and beliefs connected with the manifestation of the goddess is the most prominent religious function of the erstwhile Malabar region. Hence the news papers vie with one another in the live reporting of the various ceremonies. Folklore is reported by the various news media in entirely different styles, manner and methods. 
Mathrubhumi is the daily second in circulation throughout Kerala and foremost in the Malabar region. This news paper having most subscribers and readers from the major community in Kerala (ie., Hindus) reported the flag hoisting of the ceremony of $29^{\text {th }}$ under the title head "Nattu Varthamanam" - Regional news on its third page. The report from Quilandy (nearby town to the Pisharikkavu) in its reporting on the flag hoisting ceremony, gives the details of the temple ceremonies, the Schedule of the various processions from the different localities, the musical concerts, fireworks etc. along with the timing and peculiarities of many temple festivities, traditional rituals, entertainments etc. in the coming days of the entire festival. In $15^{\text {th }}$ page of the daily we can see the 'Marketing Feature'. Eventhough the subject matter is Kaliyattam festival, description about it is too scarce in the feature. The photographs of the Board members of the Temple Trust the Officials, and the Thidambu (the idol of the goddess used in the procession of the Devi outside the Srikovil (Sanctum sanctorum) during the festival time. The diety in the garbha griha is a permanently installed one and cannot be taken out for any reason and on no account. It commands veneration and worship all throughout its entire undamaged existence) can be seen in one corner of the feature. Descriptions of the Pisharikkav or the Kaliyattam have not been given. Dailies, Malayala Manorama, Deshabhimani and Janmabhumi are silent about the first day of the festival. The 'Madhyamam' on its second page under the caption 'Nattu Vishesham' reports about the flag hoisting of the Pisharikkav Kaliyattam to be held on the same day. This daily has also echoed the epithet that Pisharikkav is the famous kavu of the North Malabar region. After the report on the rituals starting from $4.30 \mathrm{am}$ on $29^{\text {th }}$, the daily then jumps to the details of the rituals starting from the $6^{\text {th }}$ day of festival, omitting the details of the intervening days. Pointing out to the procession form the various regions of the Quilandy Taluk, daily concludes the report stating that there will be performances of various temple art forms on all the days of the festival.

The Janmabhumi Daily on the $31^{\text {st }}$, in its feature 'Pradeshikam' - (Regional News) - has given the photo of the flag hoisting of Kaliyattam. It is to be noted that dailies including this one, have not reported anything about this function in their issue on the $30^{\text {th }}$. The Malayala Manorama, the most read newspaper of Kerala also gives the report about Kaliyattam on the $31^{\text {st }}$. The reporting is seen on the $2^{\text {nd }}$ page, on its 'Varthamanam' feature under the heading 'The Pisharikkavu Kaliyattam has begun with the flag hoisting.' The Manorama which denotes that the festival commenced with the entry of the Melshanti - the main temple priest -, into the temple, who has kept away from the temple according to the custom, do not dwell upon the details of this particular custom. The details about the rituals of the $29^{\text {th }}$ have been given concluding the report. The colour photo of the 'Kazhcha Siveli' of the previous day accompanies the report. The Malayala Manorama has published a four page 'Marketing Supplement' on the same day. The first page of the supplement to be mistaken as the first page of the newspaper, as it bears the name Malayala Manorama' in bold letters, gives photo of the deity. The advertisement has been limited to one third of the page. On the second page, we can see a feature under the caption 'Pishaikkav Kaliyattam - the Pooram of Malabar'. This feature exhibiting the photographs of the flag hoisting (Kodiyettam) and Kazhcha Siveli ${ }^{8}$, saying that the festival brings about a nostalgia into the minds everyone of Kollam, gives an in depth-detailed account of the procession heralding the sword of the goddess - Nandakam. This description, pointing out to certain traditional folk collectivity, mainly focuses on the trembling Melshanti (the main priest) on the elephant in the procession. Advertisement occupies half of this page. The third page of the supplement begins with the caption - "Enchanting Entertainment items for this year's Pisharikkav Festival - (Pisharikkav Utsavatthinu Ikkuri Vismayamarnna Paripatikal). This page giving the photographs of the Trusties, Priests, the Executive of the Festival Committee and the officials of the Devaswam gives an account of the rituals and entertainment programmes from $31^{\text {st }}$ March to the $5^{\text {th }}$ April. There are short descriptions under various sub-heading such as 'the sanctum-sanctorum where the goddess of the Pisharikkavu was installed' (Pisharikkavilammaye Adhyam Prathisticha Palliyara), 'The Mural paintings of the Quadrangle of the Temple' (Nalambalathile Chumarchithrangal), Pisharikkavu and the Kondadumpadi Temple and the Eight Ancestral Families (Ettu Tharavadukal). Half of this page also is for the advertisements. In the fourth and the last page under the pictures of elephants the underscript 'The sons of the Sahya Mountain Belonging to Mangalam Kunnu in Pisharikkavu Resplendent in their Elephantine Majesty' has been seen given. In this short rendering, the peculiarities of the elephants paraded in the festival and a verbal presentation of the majestic scenes of the various processions have been included. A picture of the percussion artist, Shri Kanjilassery Marar and a special report of his performance has also been given. The Photographs of the different scenes from the Pisharikkav festival rites such as Kodiyett, Ezhunnellathu (procession), the temple authorities, the Akampadi Chettis (members of those special castes who have the right to accompany the procession of the goddess), the Ayirathiri Choriyal (The ritual of presenting thousands of lamps to the deity), Komath Pokku ${ }^{9}$, Aringad Eriyal ${ }^{10}$, Valakamkootal etc. are given. As usual, the left out portion is devoted to commercial advertisements. On April $2^{\text {nd }}$ the importance and primacy of the Pisharikkavu festival has been recognized by the Malayala Manorama, Mathrubhumi and Janmabhumi dailies by giving the photographs of 'Kazhcha Siveli' in their second page under the different headings 'Regional-Pradashikam', 'local News Nattuvarthamanam' and News respectively. All these papers carry the same photograph made available by a 
professional photographer. The Mathrubhumi Report is under the heading, 'Pisharikkav Kaliyatta Festival Insurance coverage to the Devotees.' The Malayala Manorama Headline goes as 'Rush of Devotees to Pisharikkavu Seeking Blessings.' In its report of April $3^{\text {rd }}$, the Mathrubhumi has given a report of the Pisharikkav festival in its second and third pages under the heading Nattu Varthamanam eulogies of the Percussion Renderings (Chendamelam) by celebrated artists, descriptions about the Cheria Vilakku and the presence of peddlers etc. have been the subject of the reporting. The temple rites upto the final day of the festival have been indicated. News of the festival has been given by the Malayala Manorama in its second page under the headlines 'Cheriya Vilakku Today in Pisharikkavu' and 'The Customary Arrival of Vannan in the Morning.' This portion includes reports about the 'Customary Arrival of the Vannan', 'Komath Pokku' (Procession to the Komath house), various processions, stage programmes, insurance coverage, Annadana (Offering of food to the devotees), the services rendered by the Health Department of the State and the presence of the Fire Force contingent etc. The Janmabhumi has given only the photograph of the 'Kazcha Siveli'. It has to be noted that all the three newspapers have given one and the same photograph. The $15^{\text {th }}$ page of the daily has been made into a Marketing Feature by the Mathrubhumi on April 3. Under the headline 'Cheriyavilakku Today in Pisharikkavu', we can see the sub title 'Festivities of Kudamattom in the minds of the Devotees' (Kudamattom is peculiar to Trichur Pooram where umbrellas of different shapes and these are exhibited in succession by the Tiruvampadi and the Paramekkavu sides facing each other on 15 elephants each). This feature comprising 2/3 portion of commercial advertisements has been prepared by Dr. K.C. Vijayaraghavan and Dr. Jayasree. It is to be noted that the feature enlightening on the processions, Religious Harmony, The Rights of the Down-trodden, The Relevance of the Kavu etc. tries to satisfy and serve the interests of the secular and proletariat streams of thought. The Madhyamam, Janmabhumi, Mathrubhumi and Malayala Manorama have given the news in connection with Cheriyavilakku on April 4. All the four have given the same photograph pertaining to the rite of 'Komath Pokku.' While the Janmabhumi has given the news on its $3^{\text {rd }}$ page, all the others have given it on their $2^{\text {nd }}$ page. In the Mathrubhumi, the report is under the Headline 'Anugraham Chorinju Pisharikkavilamma Innu Purathezhunnellum' (The Pisharikkavilamma will visit the vicinity around the temple showering blessings to the devotees). The report gives a very brief report on the rites of the previous day and continue with the details of the rites on the day of the Cheriya Vilakku. The presence of the elephants and the police also has been denoted. Reports about the 'Festival Season of the Elephant Fans' and the 'Valour of the Police Force' have been given on the $15^{\text {th }}$ page. The temple rites of the entire day have been detailed by the 'Malayala Manorama' under the headline 'Valiyavilakku Today in Pisharikkavu'. News about the traffic control has been given under this report. Janmabhumi gives a report under the title 'Koyilandy and the Surroundings in the Spirit of the Festival.' It renders the news in the sequence of tomorrow, today and yesterday and reports Pisharikkavu Valiyavilakku Today' and 'Kaliyattam Tomorrow.' The Madhyamam winds up the news in three sentences giving the caption 'Pisharikkavu Valiya Vilakku Today' under the photo. The $12^{\text {th }}$ page of the Janmabhumi is Pisharikkavu Supplement. In this page, commercial adverstisements occupy two-third portion. The headline is Bhakthiyude Niradeepamayi Kollam Pisharikkavilamma' - The Mother goddess of Pisharikkavu in the Beacon of Devotional Splendour.' Above this, the nocturnal spectacle of the Nadappanthal and the grandeur of the Shiveli are given. The legend about the Pisharikkavu, the descendancy of the Trustees and a write-up on the festival etc. are given in the report. There is a report on the services of the organization 'Seva Bharathi' 12 as the concluding part.

The Deshabhimani also on April 5, joins the chorus of the reports of Valiyavilakku. The photographs of the Shiveli on the day of the Valiyavilakku can be seen on the left upper part of the report. The news Kaliyattam Today in Pisharikkavu' gives a description of the Valiyavilakku and the ensuing ritual of Kaliyattam. There is a report on the traffic jam in the N.H under the Headline 'Traffic Jam in the N.H from the Early Morning' and mentions of the traffic control of that day. The 'Madhyamam' in its last and $14^{\text {th }}$ page gives the photos of elephant and percussion performance of the Shiveli carrying the headline 'Kaliyattam Today in Pisharikkavu'. The news has been given in the sequence of the rites of the ensuring Kaliyattam, the schedule of the previous days Valiya Vilakku and the arrangements of traffic control. Janmabhumi in its section 'Pradeshikam' gives the photo of the Procession of Vasurimala (The goddess of the smallpox) clearly showing the elephant and percussion artists. 'Kaliyattam Today in Pisharikkavu' is the headline of the not so unique news describing the details of the previous day's Valiyavilakku and the rites in connection with Kaliyattam. The Malayala Manorama on the right portion of its first page gives the photograph of the Shiveli under the caption 'Devikadaksham' - The Blessings of the Goddess. 'Valiyavilakku in Pisharikkavu' 'Kaliyattam Today' etc. are the captions of the news given on the third page 'Varthamanam'. Half of the page of 'Nattuvarthamanam' of the Mathrubhumi Daily has been occupied by the news from Pisharikkavu. The enchanting headline 'Thousands Participate in the Valiyavilakku of Pisharikkavu - the Locality Barking in the Festivities' has been given to the photo of the procession of Vasurimala. The subtitle 'Mahakaliyattam Today' can be seen below. The report detailing the previous day's processions, gives a general report on the rites of that days 'Kaliyattam'. The news items 'Flamboyant Kaliyattam Mahotsav' gives a description of various entertainment and shows 
accompanying the processions. In the item 'Salt rod procession on the Kaliyattam day', describes the procession from the Kadalur Bhagavathi temple. This denotes the rite of bringing sufficient salt required by the deity sufficient for a whole year. 'Water Sprinkled to Contain Dust' was another news item. It must be noticed that the marketing feature of the Mathrubhumi is of one and a half page. 'Kaliyattam Today in Pisharikkavu' is the caption of both the pages. The writings about 'Kodiyettam' (Flag hoisting), Ooralanmar (temple owners), Ezhunnellathu (Procession), Varavukal (Ceremonial parades), Akampadi Chettimar (Chettimar-members of a certain caste - accompanying the parades or processions), Ayirathiri (Thousand lamps), Malakkali. Komath Pokku (Procession to the Komath Family),. Valakamkoottal (Installation of Devi's sword in the sanctum sanctorum) etc. occupy only one-third of the total space; the remaining portion being set apart exclusively for advertisements.

The Janmabhumi gave the photo of the 'Nandakam Procession' on its first and news on the third pages as its treatment of the Kaliyattam Festival on the $5^{\text {th }}$ of April. In its featue 'Pradeshikam' (Regional News), gives reports on the unprecedented crowd and various rites of the day. Under a sub-heading the fire-work accident where nine persons sustained injuries has been reported. The 'Madhyamam' elaborated on the conclusive rites of the Pisharikkavu Kaliyattam.' The fireworks accident has been dealt with in a box item. The Deshabhimani, first of all, in its first page, engages the firework accident giving the photographs of the nine persons injured. In the last portion of the same page, the photo of the 'Nandakam Procession' has been given, describing the valedictory rites of the function. The Mathrubhumi had given the photo of the Nandakam Procession' and reports about the final rites and the stampede occurred as a result of the rumour of an elephant running amuck etc. The reportings on the eight day long Pisharikkavu Temple Festival are given going into the manner attitude and details of the same.

\section{Analysis Of The News}

The dailies like the Malayala Manorama, Mathrubhumi, Madhyamam, Deshabhimani and Janmabhumi have specific reporting styles and inherent political attitudes. Of these, the Malayala Manorama is first on the circulation statistics. This daily, which is depended up on by the Christian community and the members of the majority community of the southern region of Kerala for news and analysis has got a considerable circulation in the Malabar region as well. It has not antagonized the non-Christian communities at any instance. The Mathrubhumi is the traditional daily of the Malabar region and is, therefore, widely read and appreciated by the majority community. Its 'Soft Hinduist' attitude is widely proclaimed. In the Malabar region, where the communist ideology is having deep-rooted influence, the Deshabhimani daily has got wide circulation. The 'Madhyamam' is the mouth-piece of the Jama-te-Islami Alhind. Eventhough the Islamic Empowerment is its avowed aim, its readership comprises of the members of the non-Islamic communities also. The Janmabhumi, even though being the mouthpiece of the Sangh Parivar, gives importance to the Hindu spiritual zone. In short, all these dailies give stress for incidents of national importance. They also set apart three to four pages for regional news. When we examine the news items in these dailies, it can be observed that the folklore does not get due representation. These dailies give precedence to folklore items involved in festivals like Onam, Vishu, Christmas, Bakrid, Muharam, Id, Sabarimala season, Kodungallur Bharani, Kottiyoor Vaisakha Festival, Guruvayur Festival, Maundi Thursday, Easter, Attukal Ponkala etc. The other folklore festivals of local or district level are dealt within the regional features and news items. Some of them do not get coverage in the entire district editions. The news about Kollam Pisharikkavu Festival were given only in the Calicut Editions of the different dailies. This is because this festival involves and unites the people from the coastal region (Arayas) to those who dwell in the hills and forest regions (Malayas) of the present day Koyilandy Taluk, thus encompassing the entire area. But these dailies do not go into the details of the legends and beliefs of the entire society and the part played by each of the communities spread over the area in conducting the various specific rites constituting the whole festival. Only a few folks got treatment in the news items. On observing that the photographs of the Ooralanmar (the temple owners), the Thantris (the parent members of the family who earlier installed the deities) and the Melshantis (The main Priests) are only given in the reports, the principle that administrative and economic powers generate and control news can be deduced.

Since the news items are interspersed with the reporting about the traditional rites as well as the entertainment items of the festival, the readers are not able to get a whole picture of the entire view point of the folk collectivity in the conduct of the Kaliyattam festival. Almost all the features present devotional rites in literary language. One of the news item presents the secular elements of the kaliyattam (Mathrubhumi - April 3, 2013). The presence of certain communities has been justified in this item.

Some dailies have described the festival as the Pooram of the North Malabar (Malayala Manorama March 31, Pisharikkavu Festival Marketing Feature page, 2). The reports and photos given by them in justifying the equation with the Trichur Pooram ${ }^{13}$ are note-worthy. It has been observed that eventhough the number of elephants here are not as much as in Trichur Pooram, the practice of engaging elephants is on the increase in Local Processions. Percussion teams also have become fabulous. The special symbols of Trichur 
Pooram are the elephants, ornamental Umbrellas and the percussion performances. All these can be observed to be employed in the Kaliyattam festival as well. But the uniqueness of the Kaliyattam cannot be denoted and described with these three. But giving the photographs of these three and suffixing comparable descriptions, the Kaliyattam is equated and accentuated with Trichur Pooram. The influence of the media in the wide employment of elephants and percussion teams in regional festivals is to be subjected to analysis and evaluation. Festival is an analytical genre in the study of folklore. Trichur Pooram is the case example of the media for a festival. The local and native elements of the festivals are being increasingly down-played by the journalists. Thus the media becomes incapable of describing and highlighting the ethnic genre of the festivals like the Kaliyattam. This is so because of the ignorance or the negligence of the media towards the folklore arena.

The features on the folklore is a treasure-trove of advertisements for the dailies. Almost all the festivals are dealt within the space for Marketing Features. The festival seasons are made use of for advertising the local commercial and industrial establishments. Advertisements of the establishments and firms of the local areas such as Koyilandy, Calicut, Perambra or Vadakara are seen to be given in the Marketing Features of the festival. When the commercial advertisements surge, the space for descriptive items dwindle accordingly, thus limiting the scope and space for the festival reports. In short, newspapers give importance to advertisements over folklore. News, viewing the folklore according to the practice and beliefs of the folk do not get generated. Newspapers do have the outlook that folklore touches and awaken the mental plane of the folks. By including the representation of the folklore in the news items, the publishers of their newspapers win the confidence of the folk, thereby increasing their circulation. That is the reason why we see an increased interest in reporting items related to folklore. The above mentioned news reports about Kollam Pisharikkavu reinforces the above conclusion. It is to be mentioned that the present day style of reporting and journalistic activities are not conducive to presenting the view points of the folk on their lore and hence the need for a new genre of journalism called 'Folklore Journalism'.

\section{Folklore Journalism}

All the incidents and occurrences in a society are raw materials as far as a journalist is concerned. Journalism is the process of refining these raw materials into news. Journalistic Branches numbering to about fifty, resort to this method. Barring the genre of Citizen Journalism, where the readers get an opportunity in generating and circulating news, people and their life are raw materials and journalists are super human specimens engaged in refining them. Taking Automobile Journalism for instance, it can be seen that this branch presents new models of vehicles are describing their peculiarities in detail. In Motoring Journalism, Automobile Engineers, well-versed in the branch, disseminate the particulars of the vehicle, in a language and vocabulary easily discernible to the common man. Art Journalism, Crime Journalism etc. are handled by experts in the field. Presently Folklore is also considered mostly as a raw material - a device utilized by the dailies to enhance tariffs and increase circulation. Folklore is also a communication process in a specific cultural and social context and therefore, is an ethnic symbol. Hence when this is subjected to news generation, the policy and the aspirations of the folk are to be reckoned as a prime consideration. The refining or news generation should be conducive to the view points of the folk. What is relevant is the attitude of the folk and not the interests and policies of the publishing house or the journalist.

Festival, which is a Folklore Genre, has been dealt with in this paper. But this genre is not an exclusive one. A festival is an occasion where various genres of physical, ritual, entertainment, faith, vocation etc. are integrated and fostered. Therefore, the genre of festival is analytical in its nature. Its basis is academic classification. Kaliyattam is an Ethnic or Native genre and this classification is according to the view point of the folk. This is the regional version of the festival. Pooram is the name of the festivals in Trichur city or the Trichur District. Kaliyattam is of the erstwhile Kurumbranad Swarupam (a chiefdom). Eventhough, both Pooram and Kaliyattam can be included in the academic classification of festivals, they are quite different in their ritual, conceptual and structural aspects. And hence when the Kaliyattam festival is considered in its cultural vicissitude and Pooram considered in its socio-cultural situation and subjected to reporting, then entirely different new items will be the result. One cannot be equated with the other.

The reckoning of a folklore within the folk and sub-folk need not be identical. Or there will be differences in the degree of understanding. There can be differences within the folk as well. All these are texts in the study of folklore. A single folklore can have more than one texts. Folklore is to be subjected to news generation by considering all these texts, taking them to be different versions reflecting the intrinsic uniqueness of the folk and sub-folks within it. Of the entire Varavu (Processions) in the Kaliyattam, if we are to consider the Arayante Varavu (Procession of the Fisher folk), the notion of the folk and not of the Ooralas (the Temple Owners) are to be examined. Both will be entirely different. As far as the Ooralas are considered, the processions are viewed as a means to collect materials and substances required for the different needs of the temple. For folks involved, it will be live reminiscence of the centuries old relation with the Devi (goddess) and other connotations that will be in periphery and depth of their folk mind. The functions of the procession, the 
special status given to the Araya folk in the festival, the assessment and understanding of the general public (Mass) as well as the members of the Araya Community in this regard etc. are to be reckoned in reporting such reports should educate the special tasks, undertaken and performed by the community in consummating the entire festival. The journalist, instead of viewing the different small folk communities from without, should evolve a mechanism of generating the news on the basis of analyzing the entity's internal deliberations. Then only folklore Journalism will come to be evolved. The folklore, which is an artistic communication with in the limits of a small collectivity ${ }^{14}$ is very dynamic in nature. It may diffuse to the outside world in its stages of evolution. The dissemination through the media is the most important of these diffusions. It is, in a, way a propagation. Many factors are to be taken into consideration when folklore is converted in to news or subjected to news generation and propagated through the mass media. The folk situation of the folklore, the description of the constitution of the folk, the origin of the folklore, the beliefs connected with it, the execution of the various rites, the wisdom conveyed through it, its functions, the attitude of the folk towards it etc. are to be dealt with, without forsaking the authority of the folk over the lore, while subjecting the folklore for news generation. For such a folklore reporting to be plausible, a deep orientation in folklore study is highly essential. Instead of the technical knowledge in journalism, the requirements are the knowledge in folkloristics and faith in the capacity of the folklore in the upkeep of the morality and courage of the people.

\section{Conclusion}

Only a journalist with a profound understanding of the folklore well-versed in agriculture, various customs and rites, different dialects etc. will be able to present such a reporting. Any folklore is to be subjected to reporting connoting to the socio-cultural situation of traditional methods of farming, medicines, customs, rites, entertainments, food habits etc. Various questions and considerations such as what is a lore, what constitutes a folk, what are the assumptions of the folk on the lore, the depth of the relation of folk with the lore, its execution and performance its various interpretations knowledge about other folklore supporting the particular one and other folk, how the folk represents itself and the world through the lore, the outside interventions on the lore, changes occurring in it etc. are the various concerns and main planks of the Folklore Journalism. News, features, write-ups, interviews etc. are different media genres to be employed in Folklore Journalism.

Folklore is to reported on the fundamental lesson that folk is to be understood and evaluated on the basis of the lore. In short, Folklore Journalism is the new genre in journalism to help a general society (mass) understand the lore conducive in discovering and recognizing the folk for a correct and succinct appreciation of their perceptions.

\section{Notes}

1. The world 'utsavam' can be generally translated into English as festival. The annual rituals in the temples and 'kavus' are denoted as 'utsavam'. The observation on some particular days, certain rituals and cultural reparatory rites can be called an 'utsavam'.

2. "The dance (Attam) of Kali" is the word meaning. Kaliyattam is the annual ritual in Bhadrakali temples, especially in those where the Sakteya system of worship is practised. The ritual of Kaliyattom of Pisharikavu is celebrated as a festival. Pisharikkavu is a temple located at the Koyilandy Taluk of Kozhikode district in northern Kerala. This Kaliyattam festival is celebrated in the Malayalam month of Meenam. The festival is celebrated with pomp for eight days. The $7^{\text {th }}$ day is celebrated as 'Valiyavilakku' and the $8^{\text {th }}$ day as Kaliyattam, on which days; the divine Nandakam sword is brought out and circumambulated around the temple on a fully decorated female elephant.

3. The Malayalam Manorama is the newspaper in Malayalam with the highest circulation rate. It started publication in 1888 with Kandathil Varghese Mappila as editor. This newspaper with numerous editions and has got various other subsidiary publications.

4. The Mathrubhumi daily is the second in circulation in Malayalam. It started publication in 1923 from Calicut. K. P. Kesava Menon was its first editor. This daily heralded the freedom movement in Kerala.

5. Presently the mouthpiece of the communist Marxist Party of kerala. Began publication in 1942.

6. Began publication in 1987 from Calicut. It is known as the mouthpiece of the Jama-ate-Islami.

7. Began publication in 1977 under the ownership of the Mathruka Pracharanalayam. Late Prof. M. P Manmadhan was the first editor. The aim of this newspaper was the Hindu renaissance. The mouthpiece of the R. S. S.

8. Siveli or Sribhuta Bali: This is an important rite in temple worship. It is the culmination of the puja (worship). The deity (devata) comes out after accepting all the pujas. At this time, puja of the accompanying deities (Parivara Devatas) outside the temple is offered. This is the Sribhuta Bali. It is actually the offering to all the creatures including the birds and insects. The Utsava Bali is the developed form of this Sribhuta Bali. Kazhcha Siveli is a part of the Utsava Bali. 
9. The chief oracle (komaram) goes to the Komath family on the day of the Cheriya Vilakku. This is a journey to invite the members of the Komath family for the Kaliyatttam and a rite of offering blessings to the family who in ancient times offered land for the construction of the temple. The devi is believed by some to have been resided in the puja room (Padinhatta) of the Komath family.

10. There is a rite in the Pisharikavu of giving offerings to the Bhutaganas (the set of deities outside the temple) after the Kaliyattam. This is termed as Aringad Eriyal.

11. The procession of the deity (Bhagawathy) on the day of the Valiya Vilakku is the most important. The sojourn of the deity around the vicinity of temple in a procession with accompanying percussion and musical sets is very famous. The dance performed by the Theyyampadi Kurup as the representative of the Devi under a tree (pala) is an important part of it. It is believed that Bagavathy gets back to the sanctum sanctorum (srikovil) after the dance. The return of the Nandakam, the sword possessing the spirit of the devi to the Srikovil is called 'Valakam Koottal.'

12. Seva Bharati is an N.G.O for the service of patients and destitute. This is an organisaton under the ambit of the Rashtriya Swayam Sevak Sangh (RSS).

13. Festival is a shared sequence of emotional experiences based on symbolic interaction (Dorson, 1972, p. 170).

14. "Folklore is an artistic communication in small groups" (Dan Ben Amos, 1982, p.14).

\section{References}

[1]. Allan Stuart, (2012) The Routledge Companion to News and Journalism, London and Newyork, Routledge Taylor and Francis Group.

[2]. Amos, Dan Ben, (1982): Folklore in Context-Essays, South AsianPublishers Pvt. Ltd. New Delhi.

[3]. Dorson, Richard M. (ed.) (1972) Folklore and folk life, Chicago: The University of Chicago.

[4]. Dundes Alan, (1965): The Study of Folklore, Prentice- Hall, Inc. Engle Wood Cliffs, N.J.

[5]. Dundes Alan, (1978): Essays in Folkloristics, Folklore Institute, Meerut.

[6]. McQuali, Denis, (1996): Mass Communication Theory, Sage Publishers, New Delhi.

[7]. Payyanad, Dr. Raghavan (2013) Methodology for Folkloristics, centre for Advanced studies and Research in English Language and Literature, Farook College, Kozhikode.

[8]. Vishnu Namboodiri. M.V. (2000): Folklore Nikhandu, The State Institute of Languages, Thiruvananthapuram. 